\title{
An Analytical Network Process Approach for Strategy Priority in Islamic Microfinance
}

\author{
Naelati Tubastuvi \\ Universitas Muhammadiyah Purwokerto \\ naelatitubastuvi@ump.ac.id
}

\begin{abstract}
This study aims to identify problems that limit the empowerment of BMT (Baitul Maal Wat Tamwil) in Indonesia as well as to get solutions and strategies to improve it. Using Analytic Network Process (ANP), it reveals 5 main problems namely Human Resources, Management, Market, Technical, and Legal Problems. Legal aspect becomes the priority of problem and solution, that is the lack of guidance and supervision of BMT and the need to form a deposit insurance corporation for BMT. Kendall's (W) values that are quite high, between $0.569-0.736$ indicates that there are some agreements and consensus between practitioners and experts in their opinion related to their views of the problems and solutions for empowerment of BMTs in Indonesia. Furthermore, ANP analysis result gives alternative priority for strategies in empowering BMT that are the need of assistance and supervision from the regulator.
\end{abstract}

Keywords: BMT, Islamic Microfinance, Analytic Network Process

\section{INTRODUCTION}

Microfinance is a fast growing industry nowadays. The number of microfinance clients has reached more than one hundred million worldwide and about $90 \%$ of them were the poorest families living mainly in Asian countries [1]. Nevertheless, other data show that according to rough estimations, only $1-2 \%$ of all MFIs in the world (i.e., some 150 organizations) are financially sustainable. In most cases, these are larger, mature, regulated, and relatively well-known MFIs. Some $8 \%$ of all MFIs are close to being profitable. Both these groups of MFIs are considered to be commercial organizations, focusing on profitability and/or sustainability. A third group of organizations (20\% of all MFIs) consist of mostly NGOs, which are not yet financially sustainable, but may become sustainable in the near future. The remaining group of MFIs (70\% of all organizations) consist of smaller, start-up organizations, which are still far from being financially sustainable and are, therefore, (heavily) dependent on subsidies [2]. Various Islamic Microfinance is better known by the Indonesian public as the Baitul Maal wat Tamwil (BMT).

BMT is a micro-finance institution based on sharia principles and based on Islamic teachings. The activities of BMT are to develop productive business and investment in improving the economic quality of small and medium entrepreneurs by encouraging savings activities and supporting their economic financing [3]. the risk faced by the institution. Incidence of credit risk could originate from the lender's and the borrower's side [15]. BMTs should be able to apply risk management
BMT growth in Indonesia is quite significant. Based on PBMT data, there are 4,500 BMTs in 2015 that serve 3.7 million people with assets of around 16 trillion IDR managed by about 20 thousand people. Data at Ministry of Cooperative and SME's indicate that the number of cooperative business units in Indonesia reached 150,223 business units, in which there are 1.5 percent of cooperatives incorporated in KSPPS legal entity [4].

BMT is required to demonstrate the quality and professionalism in meeting the aspirations and demands of the people associated with economic activity. Therefore, the efforts and roles of BMT in improving the economic position of the society must show its performance in its capacity as a financial institution that has the ability to play a role in improving society's economic position and as an alternative for the community in business cooperation and partnership [5]. In order to encourage the professionalism of BMT, there is a need for involvement both from internal and external organizations. [6].

The government can channel a proportion of public budget through BMTs which will then administer and manage funds for the appropriate clients. [7], [8] and [9] argue that BMTs are able to perform multiple roles in the local community as agents of socio-economic change, charitable center or Bazis, and to become independent from government or donor subsidies. Government, donors, and development agencies have devoted substantial resources to support the microfinance movement across the world [10]. MFIs with a higher fraction of donations and regulated institutions exhibit a lower probability of social failure [11]. According to Hubert [12], MFIs with an effective governance system tend to serve large numbers of customers.

According to [13], problems faced by Islamic microfinance found in some aspects, i.e. Islamic human resources, infrastructure, market, and management. Meanwhile, according to [14], factors that inhibit the development of BMT is the inadequacy of educated and professional human resources, capital (funds) that are relatively small and limited, the existence of ambivalence between the concept of BMT sharia management with the operationalization in practice and the low level of trust from Muslim.

BMT also faces a high risk in its financing, in managing the risk, IMFIs should systematically identify, limit, and monitor

prudently, the probable occurrences of financial risks and credit risks in micro financing should not be taken lightly [16]. BMT in Indonesia have implemented an internal 
control system for their financing activities, [17] indicates that the implementation of authorization and consultation to the Sharia Supervisory Board was low.

Accordingly, statements of problems formulated in this study are: What are the problems faced by BMT in Indonesia? What are the right solutions? What strategy should be applied? Some of those questions are addressed to find the solutions using Analytic Network Process (ANP).

\section{METHOD}

This study is a qualitative-quantitative analytical study to develop the values or information represented by sharia experts and practitioners of Islamic Microfinance Institutions or BMT in Indonesia. Analytical tool used is ANP and processed using "Super Decision" software. The data used in this study is primary data obtained from in-depth interview with experts and practitioners, who have an understanding of the problems of BMT. Then, continued by filling the questionnaire in the second meeting with the respondents. The selection of respondents in this study is conducted based on the respondents understanding of the problems in the development of BMT in Indonesia.

An ANP questionnaire is presented in the form of pairwise comparison between elements in the cluster to find out the ratio of influence and how much its difference. The scale used is the numerical scale 1-9 to translate and measure from the verbal assessment [18].
This research phase begins with ANP model constructed based on theoretical and empirical literature review, also by giving questions to BMT experts and practitioners as well as by in-depth interview to examine the information more deeply to find the real problem. Furthermore, model quantification is done using questions in the ANP questionnaire between elements in the cluster to find which of the element has the greater influence (more dominant) and how big the difference is through 1-9 numerical scale. Elements in the cluster are measured to know which of them is greater (more dominant) and how big the difference is through numerical scales 1-9. To determine the results of individual assessment of the respondents and determine the results of opinion in one group is done by calculating the geometric mean. The pairwise comparison question of the respondents combined to form a consensus [19]. The final step is done by calculating the rater agreement to show the level of agreement of the respondents (R1$\mathrm{Rn})$ to a problem in one cluster. The tool used to measure the rater agreement is Kendall's Coefficient of Concordance ( $\mathrm{W}: 0<\mathrm{W} \leq 1)$. $\mathrm{W}=1$ indicates perfect fit [18].

\section{RESULT}

Problems in the empowerment of BMTs in Indonesia can be divided into 5 aspects consisting of Human Resources, Management, Market, Technical, and Legal aspects. The whole clusters are grouped into cluster problems, solutions, and strategies, shown in Figure 1.

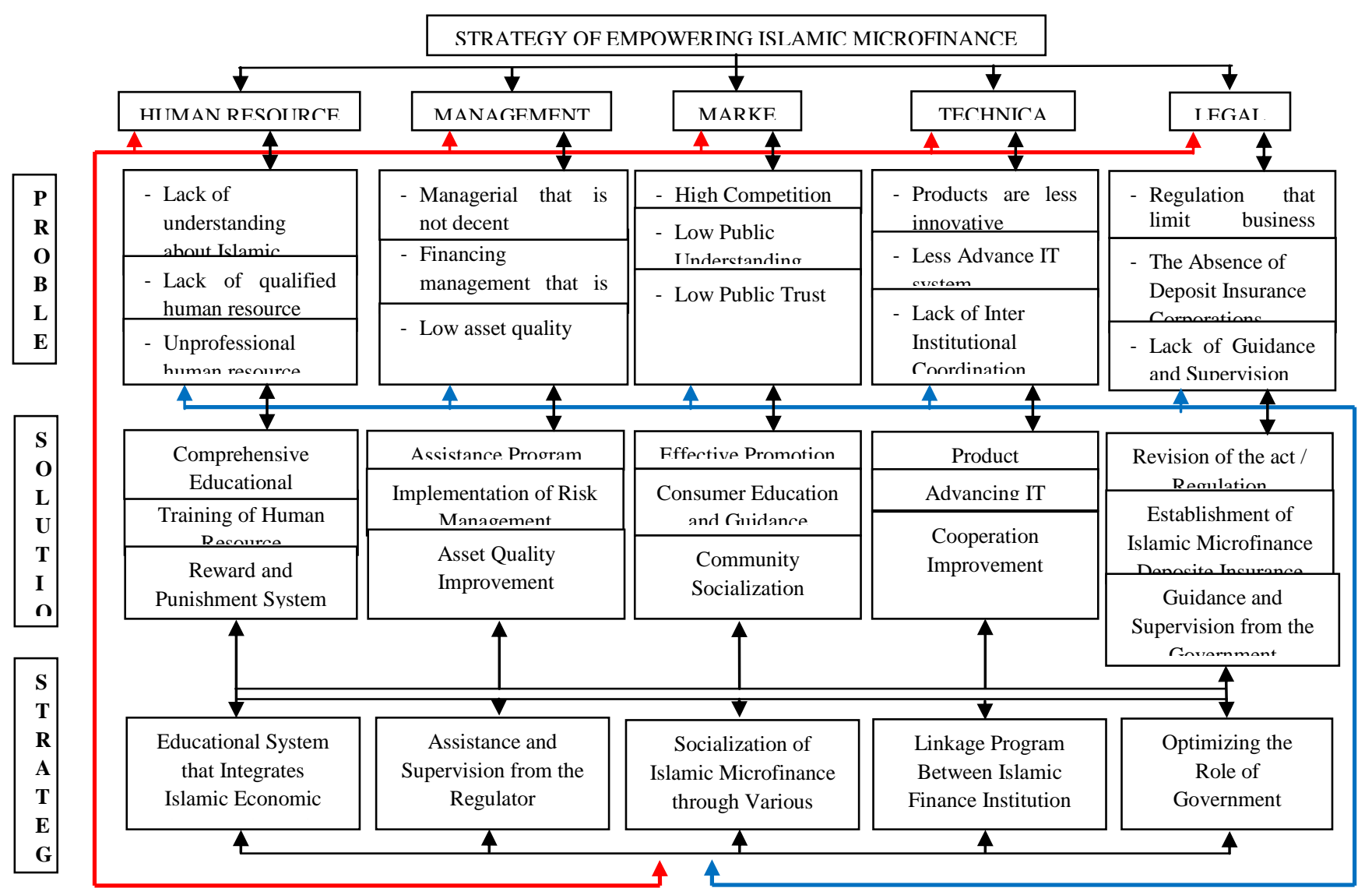

Figure 1. ANP Network Structure 
Data obtained from questionnaires were processed using Super Decision 2.0.8 software and the results are as follows:

\section{Problem Priority}

The result calculations show the consensus of experts and practitioners related to the problem of empowerment of BMT in Indonesia, indicated by the value of a large rater agreement that is $\mathrm{W}=0.617$, in general experts and practitioners assume that the legal and management issues are the most important aspect followed by the market, human resources, and technical problem as shown in Figure 2:

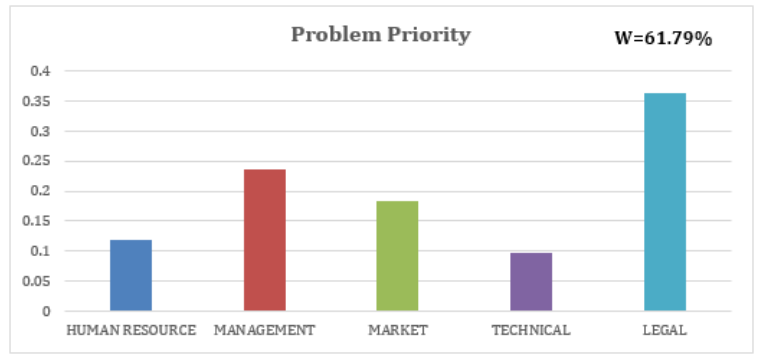

Figure 2. Problem Priority

In the aspect of problem priority, experts and practitioners agree that there is a crucial problem in terms of the lack of guidance and supervision of BMT, the absence of Deposit Insurance Corporations and regulation that limit BMT business space, with high rater agreement of $(\mathrm{W}=0.736)$. Figure 3 shows the results of cluster problem and priority calculations.

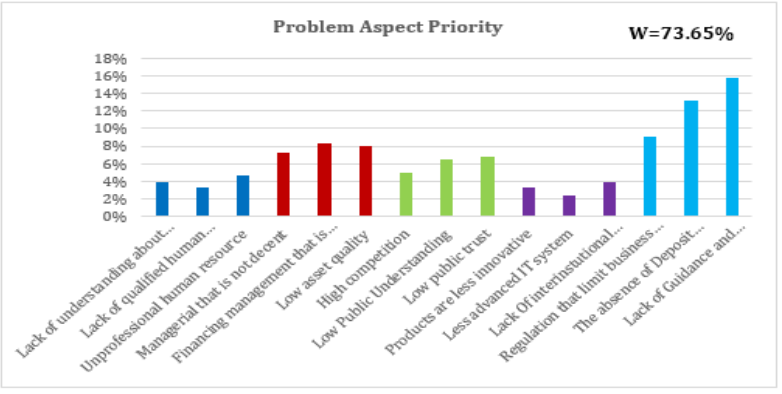

Figure 3. Problem Aspect Priority

\section{Solution Priority}

The calculation results show the consensus of experts and practitioners related to the solution of empowerment of BMT in Indonesia, indicated by the considerably high value of the rater agreement that is $\mathrm{W}=0,569$, in general the experts and practitioners assume that the legal and management solution is the most important aspect, as shown in the Figure 4:

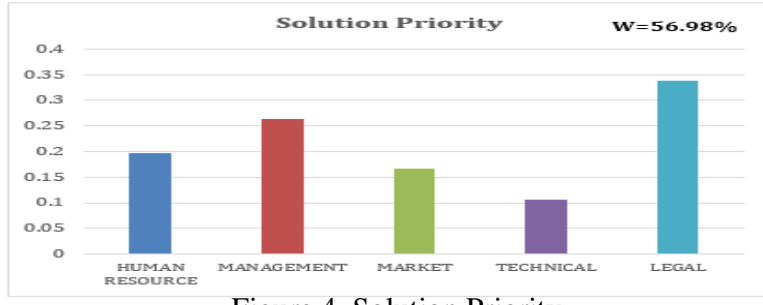

Figure 4. Solution Priority
In the aspect of solution priority, experts and practitioners agree that to solve the problem in the empowerment of BMT requires establishment of a special Deposit Insurance Corporation for Islamic microfinance; Government guidance and supervision for BMT; and Revision of the Act / Regulation that does not support BMT development and practices. The rater agreement value is big enough $(\mathrm{W}=0.708)$, this high number indicates the agreement of experts and practitioners. Figure 5 shows the results of the solution cluster calculation and its priorities.

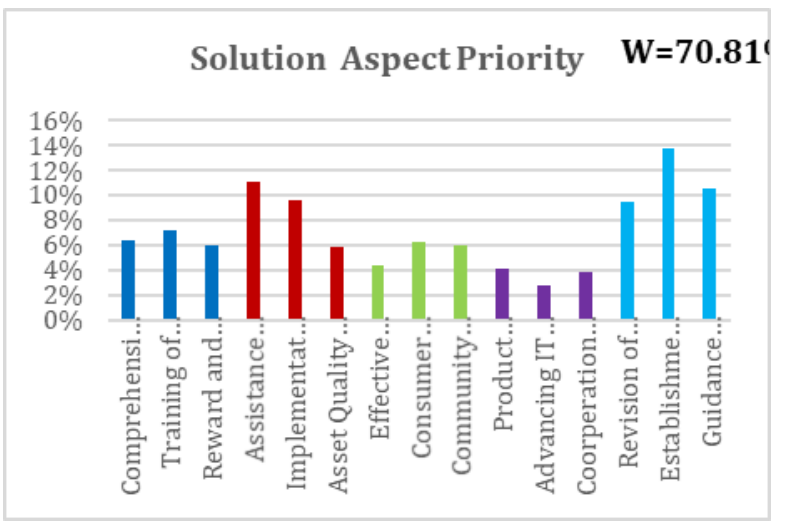

Figure 5. Solution Aspect Priority

ANP analysis results also generate alternative strategies in the empowerment of BMT. Based on the calculation of geometric mean, according to experts and practitioners, the first priority of strategy is the existence of assistance and supervision from the regulator.It is important to overcome the problem of managerial and regulatory skills that are perceived to narrow BMT space.

The priority order of strategies has a rather low value of rater agreement $(\mathrm{W}=0.369)$, this indicates that the responses of respondents related to the prioritization of strategies are quite varied. Complete picture can be seen in Figure 6:

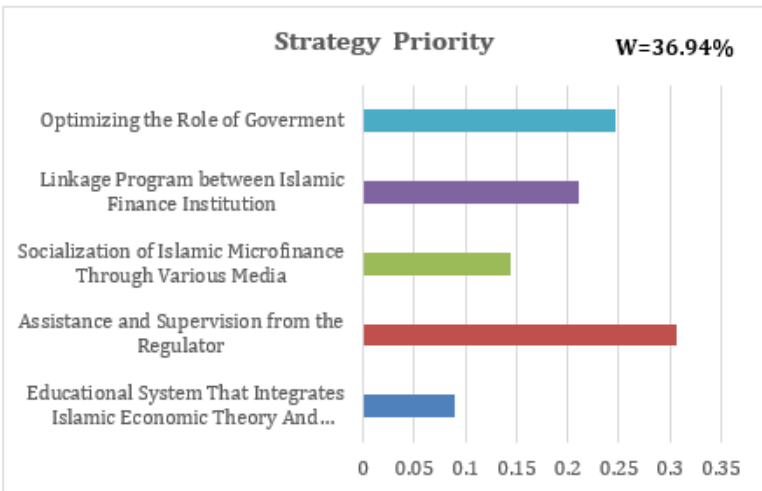

Figure 6. Strategy Priority 


\section{CONCLUSION}

This study concludes that the problems emerged in the empowerment of BMT in Indonesia consists of 5 important aspects, which are Human Resource, Management, Market, Technical, and Legal Problems. The results of the analysis indicate the priority of the solution in solving the problem consist of: 1) Establishment of Islamic Microfinance Deposit Insurance Corporations for BMT; 2) Guidance and Supervision from the Government; 3) Revision of the Act / Regulation that does not support BMT development and practices; 4) Assistance Program; and 5) Application of risk management. The ANP analysis resulted alternative strategies in empowering BMT, namely: providing assistance and supervision from the regulator, optimizing the role of government, establishing linkage programs among Islamic financial institutions, BMT massive socialization through mass media, and the educational system that integrates Islamic economic theory and practice.

\section{REFERENCES}

[1] Fernando, N. "Managing microfinance risks: Some observations and suggestions". Asian Journal of Agriculture and Development", 4(2), pp.1-22.2008

[2] Hermes, Niels and Robert Lensink. "Microfinance: Its Impact, Outreach, and Sustainability" World Development Vol. 39, No. 6, pp. 875-881, 2011

[3] Ridwan, 2013

[4] Ministry of Cooperation and Small Medium Enterprises of The Republic of Indonesia. "Menkop Puspayoga: Indonesia BMTAssociationStep in Line With Total Reform Cooperative". Available at : www.depkop.go.id/content/read. Accesed 30 Juni 2018

[5] Yusuf, Sri Dewi. "Peran Strategis Baitul Maal WaTamwil (BMT) dalam Peningkatan Ekonomi Rakyat”. Al Mizan, Vol.10 Nomor 1 pp 69-80, Juni 2014.

[6 ]Karsidi, Rahab, Rasyid Mei Mustafa. "Strategi Peningkatan Profesionalisme Praktisi Baitul Maal Wat Tamwil (Bmt) Di Kabupaten Banyumas" Performance, [S.L.], V. 14, N. 2, P. 13-34, Apr. 2018.

[7] Adnan, Muhammad Akhyar and Shochrul Rohmatul Ajija, "The effectiveness of Baitul Maal wat Tamwil in reducing poverty: The case of Indonesian Islamic Microfinance Institution", Humanomics, Vol. 31 Issue: 2, pp.160-182. 2015

[8] Nazirwan, M., "Embracing the Islamic communitybased microfinance for poverty alleviation", available at: www.mikrobanker.com/ le_article/1291215156Islamic\%20

Community\%20Based\%20Micro nance.pdf (accessed 25 Mei 2018).

[9] Widiyanto, M. and Abdul Ghafar, I. "Improving the effectiveness of Islamic microfinancing”, Humanomics, Vol. 26 No. 1, pp. 66-75. 2010

[10] Gul, Ferdinand A., Jyotirmoy Podder And Abu Zafar M. Shahriar, "Performance of Microfinance Institutions: Does Government Ideology Matter? World Development Vol. 100, pp. 1-15, 2017

[11] Dorfleitner, Gregor., Christopher Priberny, Michaela Rohe, "Why do microfinance institutions fail socially? global empirical examination", Accepted Manuscript, Finance ResearchLetters, 2017. doi: 10.1016/j.frl.2016.12.027

[12] Hubert, T. T.'Determinants of the governance quality of microfinance institutions", Accepted Manuscript, Quarterly Review of Economics and Finance .2015 http://dx.doi.org/10.1016/j.qref.2015.02.011

[13] Darwanto, "Strategi Penguatan Microfinance Syariah Berbasis Ekonomi Kelembagaan" Inferensi Vol. 8, No. 2, pp 501-522, Desember 2014

[14] Rusdiana. Aam S. dan Abrista Devi, "Challenges In Developing Baitul Maal Wat Tamwiil (Bmt) In Indonesia Using Analytic Network Process (ANP)", Business and Management Quarterly Review, 4(2), 51-62, 2013

[15] Kassim, S. and Rahman, M. "Handling Default Risks in Microfinance: The Case of Bangladesh". Munich Personal RePEc Archive. 2008. [online] Available at: http://mpra.ub.unimuenchen.de/id/eprint/16123 [Accessed 4 May 2018]

[16] Manan, Siti Khadijah Ab and Muhammad Hakimi Bin Mohd Shafiai. "Risk Management of Islamic Microfinance (IMF) Product by Financial Institutions in Malaysia" Procedia Economics and Finance 31 pp 83 - 90. 2015

[17] Wardiwiyono, Sartini "Internal control system for Islamic micro financing: An exploratory study of Baitul Maal wat Tamwil in the City of Yogyakarta Indonesia", International Journal of Islamic and Middle Eastern Finance and Management, Vol. 5 Issue: 4, pp.340-352. 2012

[18] Saaty, Thomas L and Vargas, Louis G. "Decision Making with the AnaliticNetwork Process. Economic, Political, Social and Technological Applications with Benefits, Opportunities, Costs and Risks". Springer.RWS Publication, Pittsburgh. 2006

[19] Ascarya,"The Persistence of Low Profit and Loss Sharing Financing in Islamic Banking: The Case of Indonesia"review of Indonesian economicand business studies vol.1 LIPI economic research center. 2011 